\title{
PSYCHOLOGICAL PREDICTORS OF SENSE OF QUALITY OF LIFE IN A GROUP OF ACTORS
}

\author{
Wojciech Napora $^{\mathrm{a}}$ and Andrzej Sękowski ${ }^{\mathrm{b}}$ \\ a Jan Długosz University in Częstochowa \\ b John Paul II Catholic University of Lublin
}

\begin{abstract}
Being a theatre actor requires specific abilities, such as the ability to function in situations of social exposure, to feel and express different emotions in a short time, and feel exactly like the character they play. This profession is perceived as unique and prestigious. The aim of this research was to establish the predictors of the sense of quality of life in a group of actors. The study involved 52 professional theatre actors. The results showed a positive correlation between the sense of quality of life and dimensions of emotional intelligence, social competences, and self-esteem. Moreover, the predictor that explains the largest variance in the subjective quality of life in the group of actors is the acceptance of emotions.
\end{abstract}

Keywords: actors; quality of life; emotional intelligence; social competences; self-esteem.

Theatre acting may be defined as an art whose main aim is reproducing identities and searching for one's own identity in everything that actors experience. Acting gives life to the character by giving them specific psychological properties and making the character seem real and substantial (Kociuba, 1996). During a performance, an actor is expected to become the character which they are playing; they should internalize the context of the character's life and feel their problems, their joy, and their sadness. It is very important to "meet" the character, taking into account their psychological details: it makes performing as the character more authentic and real-

WojCIECH NAPORA, https://orcid.org/0000-0002-4224-9563; ANDRZEJ SĘKOwski, https://orcid.org/0000-0003-1042-0941. Correspondence concerning this article can be addressed to Wojciech Napora, Uniwersytet Humanistyczno-Przyrodniczy im. Jana Długosza w Częstochowie, Wydział Nauk Społecznych, ul. Waszyngtona 4/8, 42-200 Częstochowa, Poland; e-mail:w.napora@ujd.edu.pl.

Handling editor: MARIA KAŹMIERCZAK, University of Gdansk. Received 16 April 2020. Received in revised form 27 Nov. 2020, 1 Jan. 2021. Accepted 4 Jan. 2021. Published online 2 June 2021. 
istic (Stanisławski, 2011). Actors form a unique group with special artistic education, skilled in emotion management and stage presentation, creation of emotional and situational memory. As mentioned by Mróz (2008), professional acting styles are individual and are assessed according to aesthetic, social and moral properties. Actors believe they have something important to communicate to their audience, and this conviction can influence them. Actors also dependent on their audience. Acting is an artistic profession; actors create stage characters and communicate ideas with which they can present the virtual reality of the theatre and understand its meaning. This profession allows a fictitious reality to be conjured up (Orlak, 2009). Presenting a character in accordance with the director's vision is a huge challenge for an actor (Konijn, 2000). To make this image believable for the audience, he or she has to possess specific intellectual, behavioral, and emotional qualities. A mature attitude to an artistic profession such as acting is another important factor (Mróz et al., 2017). Being an actor is strongly connected with focusing on achievements, risk-taking and impulsiveness (Mróz, 2017). Cobb and Mayer (2000) indicate that art, such as theater, has a positive and stimulating effect on the development of emotional intelligence. Actors tend to display a high level of extraversion, thus enjoying the attention they get from an audience. They are oriented towards the acquisition of social attention and have a high level of control of their own behavior (Nettle, 2005) and non-verbal expression (Friedman et al., 1980). The realistic interpretation of a character poses a difficult cognitive challenge of conveying the character's emotions, feelings, and actions, which do not necessarily harmonize with the current situation, mood, or emotions of the actor. This issue may be an obstacle for the actor to overcome. $\mathrm{He}$ or she can also observe the work of other actors, which might be helpful in performing more difficult roles. The ability to completely transform one's psyche, emotional state and behavior into another character is a skill that actors are required to possess (Goldstein \& Bloom, 2011). As shown, the area of theatrical acting has been explored by a psychologist, and the article presents new knowledge about the relationships between variables, such as self-esteem, social competences, emotional intelligence, and the sense of quality of life.

\section{Social Competences}

Social competences are a group of skills acquired in the course of life that determine the effectiveness of an individual's functioning in the social world; it refers to how individuals interact with others (Zamorska, 2015). This category of competences determines the quality of relationships maintained by an individual, as well as their adaptive abilities. Social competences are connected with emotional 
processes, cognitive abilities, and personal and cultural values (Orpinas, 2010). As Henne (2003) reports, social competences include adaptive skills, building emotional ties, communicating, and achieving one's goals. Social competences are reflected in various social situations where the given context determines the use of specific strategies. Those competences are related to the ability to achieve one's goals and maintain good quality relationships with one's peers through proper organization of one's personal and social resources. Research conducted by Banks and Kenner (1997) shows that actors are characterized by a high level of social competences, and what is more, the performance of this profession through acting naturally develops it. For actors, social competences are important in case of being a performera satisfactory performance of the actor's profession is related to the proper functioning in a situation of social exposure. The acting profession is focused on constant contacts with the troupe and the audience (Hys \& Nieznańska, 2007). Moreover, proper functioning in social exposure situation (while acting) may be positively perceived by audience and then get positive reviews and those competences are essential in case of influencing the spectators (Mróz, 2018). Hammond and Edelmann (1991) have shown that actors (compared to non-actors) are less shy, have lower social anxiety, and are less prone to information that results from social comparison.

\section{Self-Esteem}

Self-esteem is a construct based on personality, development, and social psychology and has been analyzed by many researchers (Greenier et al., 1995). James (1890) was the first psychologist to write about the concept of the self. He describes the "subjective self," or the "experiencing self"- the sphere of an individual's inner experience. As a representative of functionalism, he described the functions of individual mental structures. The subjective self is responsible for self-awareness, sense of identity, self-knowledge, self-esteem, and self-regulation. The author also points to the social self, built on the basis of other people's opinions which one encounters in one's social environment. It also distinguishes the "spiritual self," which refers to all characteristics possessed by the individual. Branden (1969) reports that self-esteem has two components: a sense of self-efficiency, the readiness to accept challenges, trust in oneself, one's thoughts, choices, and the sense that those decisions are appropriate for their situation. The second component is self-respect, the belief that the individual has the right to be happy. Self-esteem can be treated as a factor affecting the individual's motivation in relation to the tasks they perform and activities they undertake; it is a personality-forming factor. It affects interpersonal relationships, self-confidence, and social adaptation (Filist, 2012). In the context of 
public performance, a higher level of self-esteem is associated with experiencing positive emotions and a better adaptation of the individual to risky situations in public performance (Sękowski, 1989). Hys and Nieznańska (2007) report that actors are characterized by a higher level of self-esteem than non-actors. In turn, people with low self-esteem avoid situations in which social comparisons are made, avoid social exposure, and when it does happen, they function worse. Actors, on the other hand, do not avoid social comparisons, the specificity of this profession requires even constant submission to the evaluation of others. Similar results in comparing actors and non-actors were obtained by Hammond and Edelmann (1991). Konijn (2000), pointing to the essence of competences in the acting profession, emphasizes self-esteem as a factor determining the perception of oneself as a competent person. The actor strongly identifies with his professional role, and as a certain social group, actors have a sense of strong separateness. Apart from the acting profession, being an actor is a social role (Kociuba, 1996).

\section{Emotional Intelligence}

According to Goleman (1999), emotional intelligence affects learning practical skills. This author (1997) emphasizes that emotional intelligence determines success in life in many areas: science, work, interpersonal relationships; it is also a better predictor of success in life than intelligence understood as IQ. Saarni (1999; as cited in Przybylska, 2007) reports that emotional competences enable proper functioning in social situations. It includes the following elements: awareness of one's own emotions, ability to recognize emotions in others, ability to name emotions, empathy, perception of discrepancies between behavior and experienced emotions, self-regulation of negative emotions, the impact of emotional communication on interpersonal relationships, and acceptance of one's own feelings. Interpersonal communication, included in the concept of emotional intelligence, enables the efficiency of team activities, promotes decision-making processes, and facilitates conflict resolution (Dolińska, 2013).

An actor should have high communication skills, attract the attention of the spectators with his or her personality, and should be able to express any emotional state regardless of their personal situation (Orlak, 2009). As Filozofówna (1976) points out, good acting is characterized by, among others, the ability to enter various emotional states, which is confirmed by the above research. Actors achieve this by entering into a fictional reality already at the stage of practicing the role- they also recall appropriately emotionally colored events in their lives. Thanks to this, they are able to enter such a mental state that makes it easier for them to present 
the appropriate emotions and behavior on stage. Martowska, Matczak, and Jóźwik (2018) examined actors in terms of increased mental excitability - the obtained results showed that actors are characterized by a higher level of this psychological variable (in four out of five dimensions) than people who are not actors. The actors obtained higher scores on the sensory, imaginary, emotional and psychomotor scales. These psychological properties can be treated as useful predispositions in the acting profession, because the ability to imagine various situations and create specific emotions based on them is important. "Actors distinguish themselves in their willingness and capability to portray a vast array of characteristics and emotions in front of an audience" (Peters, 2001, p. 33).

\section{Sense of Quality of Life}

Quality of life (QoL) may be understood as a set of socio-economic conditions of human life that are related to the material world and objective dimension of life. It is an assessment of various aspects of functioning related to the standard of social position, health, education. Sense of quality of life is a subjective category associated with internal valuation processes taking place in various spheres of life (Mróz, 2011). According to this approach, some variables may be perceived by the individual as predictors of a high QoL sense, while, for another, they can determine its lower value (Sękowski, 2006). Quality of life in subjective terms depends on the value system of the individual and the organization of his needs and the view on the meaning of life (Mróz \& Kurzyca, 2018). The meaning of life, in turn, may be associated with "involvement in close relationships with other people, as well as with the participation and support of such organizations that favor human development by strengthening positive emotions" (Mróz, 2016, p. 184).

In the personalistic and existential concept of QoL sense, developed by StraśRomanowska (1992), it refers to the individual's personal attitude to their life. The holistic concept of the sense of quality of life, encompassing four dimensions (spheres), applies to each individual. This concept assumes that human life functions on the foundation of the following dimensions: psychophysical, psychosocial, subjective, and metaphysical. It can, therefore, be concluded that QoLsenserefers to the way of life and the problems that the person encounters, and which vary depending on the dimensions in which they function.

The first of the psychophysical spheres is recognized as biological. It is the basis of the sense of awareness and identity. In this dimension, homeostasis is important, that is, maintaining constant conditions inside the body, regardless of external circumstances. The psychosocial sphere relates to adaptive abilities and behaviors that 
increase the level of the individual's QoL sense in relation to functioning in society. Such behavior may be creative, transgressive, or innovative. The sense of quality of life in the context of this dimension is also determined by the sense of belonging, security, acceptance, and social identity. The subjective sphere is governed by the "principle of autonomy," and the specific manifestations of subjective life are: need for one's own identity, individuality, need for freedom and self-determination, need for creative activity and self-realization. The metaphysical sphere refers to the search for a deeper meaning of life in the experienced experiences, the changeability of fate, various failures, or dramas. Thanks to a holistic approach, this concept becomes universal. Despite differences between people, this concept remains useful (Mróz, 2011).

A group of actors is a special type of professional group - they are people who have a strong professional identification, have completed many years of artistic education preparing them in a multidimensional way to be actors. Regarding individual spheres of the sense of quality of life, it can be shown how the spheres are related to the properties of this profession. The psychophysical sphere is associated with the body function, including hormonal conditioning, and thus the behavior of the body, including in such a situation as a stage performance, which many people associate with stage fright and a stressful situation. The psychosocial sphere is related to the functioning of an individual on a social basis - focusing on cooperation with the team responsible for creating the performance, working with actors playing a role in the performance. The subjective sphere is characterized by the desire to be separated from the social background - the actor's profession is perceived as unique and exceptional. The metaphysical sphere refers to transcendent experiences that actors may experience while playing certain roles, strongly marked by metaphysicality.

\section{The Aim and Questions}

Having considered the theoretical relationships between social competences, emotional intelligence, self-esteem, and the sense of quality of life, the following questions were posed:

1. What is the relationship between social competences and QoL sense in the studied group of actors?

2. What is the relationship between emotional intelligence and QoL sense in the studied group of actors?

3. What is the relationship between self-esteem and QoL sense in the studied group of actors?

4. How do self-esteem, emotional intelligence and social competences predict QoL sense? 
Following an analysis of theoretical literature, these hypotheses were formulated:

1. There is a positive relationship between social competences and QoL sense in the studied group of actors.

2. There is a positive relationship between emotional intelligence and QoL sense in the studied group of actors.

3. There is a positive relationship between self-esteem and QoL sense in the studied group of actors.

4. Self-esteem, emotional intelligence, and social competences are positive predictors of QoL sense in the studied group of actors.

\section{METHOD}

\section{Participants}

The research was conducted from October 2016 to June 2018 and involved 10 theatres in Poland. The actors were selected among those who had an academic degree in acting. First, we contacted the theatres and asked for their participation in the study. Next, sets of questionnaires were mailed to them. In addition to research tools, the sets included a general description of the study and its aim, as well as information on how to complete the questionnaires. Information about the conducted research was also posted on social media (groups for graduates of acting studies), from where actors were also recruited for research. Finally, 52 professional actors took part in the study. The sample consisted of 28 males and 24 females. The youngest actor was 24 , the oldest one was 64 . The average age of respondents was $39(S D=11.8)$.

\section{Measures}

The following questionnaires were used in the study:

1. The Social Competences Questionnaire (SCQ) is a self-descriptive tool, and the items it contains are statements referring to various activities; the respondent responds to the statements on a four-point scale. The answers show how well the person would handle the specific situations. The assessment of social competence refers to the items that cover social situations; however, the questionnaire also includes non-diagnostic items that relate to other spheres of human functioning: 
technical or artistic activities. The questionnaire makes it possible to obtain results for an individual in three areas of social competences: effectiveness of behavior in intimate situations, effectiveness of behavior in social exposure situations, and effectiveness of behavior in situations requiring assertiveness. The questionnaire has high reliability indicators which range around the results of $\alpha=0.93-0.95$ (Matczak \& Jaworowska, 2001).

2. The Self-Esteem Scale (SES) consists of 10 items. The respondent indicates to what extent they agree with each of the items by responding on a four-point Likert's scale. The tool explores global self-esteem in relation to the person's positive and negative feelings about oneself. All items are diagnostic, the test itself takes 2-3 minutes, and the result can range from 10 to 40 points. The scale has high reliability coefficients, which were $\alpha=0.82$ for the group of adults (Laguna et al., 2007).

3. The Popular Emotional Intelligence Questionnaire (PEIQ), created by Matczak, Jaworowska, Ciechanowicz, Stańczak, and Zalewska, consists of 94 statements. The task of the participant is to respond by selecting an answer on a 5-point scale. In addition to the overall score, the questionnaire lets the respondent obtain a score on the following four scales: acceptance of emotions, empathy, control of emotions, understanding of emotions. The reliability of the questionnaire is high and at the level of $\alpha=0.80$ (Jaworowska \& Matczak, 2005).

4. The Modified Sense of Quality of Life Questionnaire (M-SQLQ) consists of 41statements to which participants respond using a 4-point scale and indicate to what extent they agree with statements. In addition to the overall result, the test also provides results in the following four spheres: psychophysical, psychosocial, subjective, and metaphysical. The reliability of spheres was between $\alpha=0.74-0.86$ and the overall score was $\alpha=0.79$ (Mróz et al., 2017). A modified version of the questionnaire was created on the basis of the questionnaire developed by Straś-Romanowska, Oleszkowicz, and Frąckowiak (Frąckowiak, 2004).

\section{Research Procedure}

Ten theatres took part in the study. The first step was contacting them and asking to participate. After a brief introduction which included an explanation of the purpose of the study, and after obtaining consent, the questionnaires were sent by mail to the theatres. We personally set appointments with the theatres within the Silesian Province, during which we described the idea behind the study and distributed sets of questionnaires. 


\section{RESULTS}

Pearson's $r$ correlation was used to determine the relationship between selfesteem, emotional intelligence, social competences, and quality of life. It served to illustrate the relationships occurring between individual spheres, scales, and overall results obtained from the questionnaires, and to verify hypotheses regarding the relationship between variables and the sense of quality of life in the studied group of actors.

Table 1

Correlations Between Results of Popular Emotional Intelligence Questionnaire and Modified Sense of Quality of Life Questionnaire

\begin{tabular}{lccccc}
\hline \multirow{2}{*}{$\begin{array}{c}\text { Modified Sense of } \\
\text { QoL Questionnaire }\end{array}$} & $\begin{array}{c}\text { Acceptance } \\
\text { of emotions }\end{array}$ & Empathy & $\begin{array}{c}\text { Control of } \\
\text { emotions }\end{array}$ & $\begin{array}{c}\text { Understanding } \\
\text { of emotions }\end{array}$ & $\begin{array}{c}\text { Overall } \\
\text { result }\end{array}$ \\
\hline Psychophysical sphere & $.54 * *$ & $.30^{*}$ & .21 & $.50^{* *}$ & $.48^{* *}$ \\
Psychosocial sphere & .23 & .24 & .21 & .26 & $.40^{* *}$ \\
Subjective sphere & $.30^{*}$ & .22 & .11 & .25 & $.30^{*}$ \\
Metaphysical sphere & $.33^{*}$ & $.44 * *$ & .16 & $.30^{*}$ & $.46^{* *}$ \\
Overall result & $.43 * *$ & $.39 * *$ & .23 & $.41 * *$ & $.53^{* *}$ \\
\hline
\end{tabular}

$* p<.05, * * p<.01$.

The results presented in Table 1 allow a conclusion that with the acceptance of emotions, the sense of quality of life in the psychophysical, subjective, metaphysical spheres and the general QoL sense increases. A positive relationship between the ability to empathize and the psychophysical as well as metaphysical sphere and sense of quality of life in general was also observed. The ability to control emotions does not correlate with any sphere of QoL sense. An increase in the ability to understand emotions is accompanied by an increase in the sense of quality of life in the psychophysical and metaphysical spheres, as well as at the level of overall QoL. Emotional intelligence is associated with the sense of (general) quality of life and such spheres as psychophysical, psychosocial, subjective, and metaphysical. 


\section{Table 2}

Correlations Between Social Competence Questionnaire and Modified Sense of Quality of Life Questionnaire

\begin{tabular}{lcccc}
\hline \multirow{2}{*}{$\begin{array}{c}\text { Modified Sense of } \\
\text { QoL Questionnaire }\end{array}$} & Intimacy & Social exposure & Overall result & Overall result \\
\cline { 2 - 5 } & $.280^{*}$ & .22 & .23 & .23 \\
\hline Psychophysical Sphere & .17 & .18 & .17 & .17 \\
Psychosocial Sphere & .13 & .04 & .02 & .02 \\
Subjective Sphere & $.38^{* *}$ & $.29 *$ & $.33^{*}$ & $.33^{*}$ \\
Metaphysical Sphere & $.31^{*}$ & .25 & .26 & .26 \\
Overall result & & & & \\
\hline
\end{tabular}

$* p<.05, * * p<.01$.

The results presented in Table 2 show that an increase in competences connected with functioning in situations requiring intimacy is accompanied by an increase in the sense of quality in the psychophysical and metaphysical spheres, as well as in the overall QoL sense. In relation to the effectiveness of behavior in social exposure situations, the higher the level of competence in this area, the higher QoL sense in the metaphysical sphere. There is no significant correlation between assertiveness and any dimension of QoL sense and also between general QoL sense and general social competences. The overall result in social competences positively correlates with the metaphysical sphere.

The psychosocial sphere has a strong connection with the level of self-esteem; they are compounds with a positive sign. The sense of quality of life in general also positively correlates with self-esteem (the correlation is moderate). This means that the higher the actor's self-esteem, the greater their overall QoL sense, as well as its level in the psychosocial sphere (Table 3).

Table 3

Correlations Between Results of Self-Esteem Scale and Modified Sense of Quality of Life Questionnaire

\begin{tabular}{lc}
\hline Modified Sense of Quality of Life Questionnaire & Self-Esteem Scale \\
\hline Psychophysical sphere & .07 \\
Psychosocial sphere & $.54^{* *}$ \\
Subjective sphere & .24 \\
Metaphysical sphere & .24 \\
Overall result & $.40^{* *}$ \\
\hline
\end{tabular}

$* * p<.01$. 
The next step of the analysis was establishing the predictors of subjective quality of life. A regression analysis presented below provides answers to the research questions about the extent to which explanatory variables explain the sense of quality of life. A stepwise regression analysis was performed. Variables correlating with the overall result of sense of quality of life were introduced to the models.

For the overall result of the Modified Sense of Quality of Life Questionnaire in a group of actors, there were two regression models established. Each of them is relevant. Model 1 explains 19\% of the variability in QoL sense $\left(R^{2}=0.19\right)$. Model 2 significantly increases the explained variance to $30 \%$ (Table 4 ).

\section{Table 4}

Regression Coefficients and Explained Variability for Overall Result of Modified Sense of Quality of Life Questionnaire in Group of Actors Using Step Method

\begin{tabular}{ccccccccc}
\hline & Model & $\mathrm{B}$ & \multicolumn{1}{c}{$S E$} & $\beta$ & $t$ & $R^{2}$ & $\Delta R^{2}$ & F-change \\
\hline 1 & $\begin{array}{l}\text { (Constant) } \\
\begin{array}{l}\text { Acceptance } \\
\text { of emotions }\end{array}\end{array}$ & 05.02 & 12.29 & & $7.72^{* *}$ & & & \\
\hline 2 & (Constant) & 65.12 & 14.70 & & $4.43^{* *}$ & & .17 & $11.39^{* *}$ \\
& $\begin{array}{l}\text { Acceptance } \\
\text { of emotions }\end{array}$ & 0.68 & 0.19 & .41 & $3.45^{* *}$ & .32 & .30 & $11.80^{* *}$ \\
& Self-esteem & 0.99 & 0.31 & .37 & $3.18^{* *}$ & & & \\
\hline
\end{tabular}

$* * p<.001$.

The second model explains the largest part of the variance of the variable using two predictors: acceptance of emotions $(\beta=.41 ; p<.001)$ and self-esteem $(\beta=.37$; $p<.001)$. Predictors have a positive and moderately strong effect on the explained variable and acceptance of emotions has the greatest contribution to the regression equation. The obtained results allow us to conclude that an increase in acceptance of emotions and self-esteem is accompanied by satisfaction with one's life and contributes to its positive assessment.

\section{DISCUSSION}

The hypothesis about relation of social competences and sense of quality of life was not confirmed. There is no correlation between overall results of sense of quality 
of life and social competences. The results do not correspond whatsoever with other researchers' findings on relationships between these variables. As Sarason, Sarason, Hacker, and Basham (1995) indicate, social bonds (the quality of whichis determined by social competences) are related not only to well-being, but also to the sense of quality of life. Social competences (in general) are linked with the metaphysical sphere, which is oriented towards doing good; it directs the individual towards others. Social competences allow the individual to function effectively in social situations, create satisfying interpersonal relationships, resolve conflicts, and provide support to other people. Social competences associated with intimacy situations also are related to the metaphysical sphere. The relationship between these two variables is related to building a relationship with the other person based on trust and respect. This allows a conclusion that with an increased level of competences related to functioning in closeness with other people, satisfaction with the metaphysical area of life increases. This means that such competences enable actors to perceive the other person as unique, individual. Our results show that the psychophysical sphere is related to functioning in a situation related to intimacy. This sphere of quality of life is related to physical well-being. Along with the increase in satisfaction with this area, the quality of interpersonal contacts increases, which are based, among others, on trust. Other results show a positive correlation between social exposure and the metaphysical sphere of QoL. Perhaps this is due to the fact that on stage the actor portrays a character by "being" that person, which is a unique experience. The better the ability to perform, the more actor experiences the internal world presented by acting. As Bonna (2003) points out, the art is at the same time a carrier of specific content, through which it brings the individual closer to the ideals and aspirations created by humanity, satisfies the viewers' sense of the spiritual connection with the past and present. It is worth mentioning another very important, cathartic-compensatory function of art, helping people regain their mental balance.

The second hypothesis, which assumed a correlation between emotional intelligence and QoL sense was confirmed. It was confirmed because in the studied group of actors a correlation was noted between the senseof quality of life in general and emotional intelligence. QoL sense combines with the area of human life associated with emotions. Subjective QoL increases with the level of emotional intelligence. For actors, emotional intelligence is a basic resource inthis profession. By training acting, they develop emotional skills, which - as our results showed - is correlated with the sense of quality of life. A high QoLis associated with experiencing positive emotions and with positive emotional balance throughout the person's entire life (Czapiński, 2008). An increase in the level of emotional intelligence connected with increased QoL sense is associated with an ability to cope with difficulties more effectively, solve problems and manage interpersonal communication on many levels 
(Al-Huwailah, 2017). In assessing QoLan evaluation of individual aspects of life and life as a whole is taken into account, and a comparison is drawn between ideal conditions and with other people's circumstances. Therefore, QoL can be measured from the perspective of the emotional aspect of life and the person's well-being (Oleś, 2002). Our results showed a non-significant correlation between controlling emotions and the sense of quality of life (in general and in the spheres). This result is opposite to the assumptions as it was expected that controlling emotions in a group of actors would be associated with a sense of quality of life. Perhaps the emotional control of actors is revealed to a greater extent during a play and is less intense in other areas of life.

The hypothesis which assumed that self-esteem is positively related to the sense of quality of life was confirmed - in the studied group of actors the result for selfesteem correlates significantly with the overall QoL result. People with a higher level of self-esteem evaluate their lives higher because they are able to refer to more positive experiences (Spencer et al., 1993). The level of self-esteem, as shown in many studies, influences the subjective assessment of the quality of life. This is usually a linear relationship: the higher self-esteem, the higher quality of life (Trawka, 2006). Moreover, research conducted by the same author showed that people who have a high self-esteem and declare a high sense of quality of life, do not experience a decrease in these levels in unpleasant situations (which may reduce the sense of quality of life). Similar results were obtained by Kermode and MacLean (2001): the increase in self-esteem was accompanied by an increase in the sense of quality of life. In obtained results, self-esteem do not correlate with psychophysical, subjective and metaphysical spheres. Psychosocial sphere is the only one sphere of quality of life which has significant correlation with self-esteem. The more positive assessment of an individual, the greater satisfaction with the QoL sphere, which is related to belonging with a community, maintaining relationships with others, and fulfilling social roles. A positive self-image is important for actors and for their functioning in the social world.

The next hypothesis concerning predictors of sense of quality of life was partially confirmed. Not all expected variables turned out to be predictors of QoL sense. It turned out that only one dimension of EI was a predictor. In a studied group of actors this predictor was acceptance of emotions. As Duniec (2011) indicates, acceptance of self and emotions in acting is absolutely necessary. Without it, actors cannot focus on building a role and character. Acceptance of emotions in relation to the sense of quality of life is connected with, among others, the ability to accept both positive and negative emotions (such as anxiety) which an individual may experience in public performance situations. The acceptance of emotions is also expressed by lack of manifestation of denial while experiencing negative emotions 
(Pastuszak, 2012). Acceptance of emotions is connected with the awareness of one's strengths and weaknesses, seeing oneself in a favorable light, and the ability to feel pride (Goleman, 1999). Actors should not only control their emotions, but also be able to arouse them. Moreover, receiving emotions from the audience can improve the sense of quality of life. Experiencing these emotions gives a sense of gratitude - hence the importance of emotional acceptance in the acting profession. Stage performance is associated with accepting various emotional states associated with it, for example, stage fright or, in the case of actors, various emotions appearing while playing particular roles. The increase in acceptance of emotions is accompanied by the fulfillment of specific human needs, such as the need for freedom and individuality. Thanks to this, the individual is aware of the fact that they experience their life as an extraordinary event. Acceptance of emotions means, among others, acceptance of states that come from the individual's inner sphere. This also applies to understanding body, accepting negative emotions, and accepting how one's body can respond to performance, during which the performer is observed by others (Oleszko-Molik, 2012). An increase in acceptance of their emotional states means that actors are more satisfied with the physical and mental aspect of the senseof quality of life.

In the study by Mróz (2015), in relation to a group of outstanding actors, it was found that the higher stability of the self-image of actors, the higher their self-acceptance related to needs of perseverance, reliability and independence. Higher self-image stability was related to the higher their sense of meaning of life.

Self-esteem is the second predictor of the sense of quality of life. Being an actor is associated with a sense of uniqueness and belonging to a specific social group. Higher self-esteem implies a higher subjective assessment of one's quality of life. Higher self-esteem is related to better functioning in a situation of social exposure. Self-esteem is one of the most important personality determinants of human functioning in this kind of situation. Whether an actor perceives the situation of social exposure as favorable or difficult depends on the level of the individual's self-esteem (Hys \& Nieznańska, 2001). It allows actors to perceive this situation positively and, in fact, positively influences the sense of quality of life. Exercising this unique profession requires one to follow the chosen path and to commit to it. In interviews with actors (Mróz et al., 2017), one of the respondents defines the acting professionals as one that "has the psychological luxury of doing what one likes and wants to do." It is related to the ability to "pursue the profession which one wanted to pursue" (p. 79). The sense of uniqueness is associated with the level of self-esteem, an increase in which also boosts QoL satisfaction. According to Petelewicz and Drabowicz (2016), self-esteem is largely responsible for life satisfaction and determines the level of individual's diligence. Self-esteem is associated with the sense of being 
unique due to one's work as an actor. In addition, an adequate level of self-esteem allows the individual to perceive performance as a situation which they are able to handle and meet its challenges. Self-esteem is associated with the ability to refer to many positive events in life, but also to perceive the situations one experiences from a positive perspective (Spencer et al., 1993). A person who perceives their life in this way is able to function in an interesting and productive way, as well as have a positive impact on their surroundings (Niewiadomska \& Chwaszcz, 2010).

\section{PRACTICAL APPLICATIONS, LIMITATION OF RESEARCH AND FUTURE IMPLICATIONS}

The acting profession is gaining more and more interest from researchers. The psychological variables analyzed so far make the psychological image of the actors more accurate. On the one hand, the results presented in the article provide a fresh insight in this unique profession, but on the other the research has some limitations. The results showed that the strongest predictor of sense of quality of life is acceptance of emotions. Actors may increase satisfaction with different areas of life by working on the ability of accepting different emotional states and by not manifesting their disagreement with experienced emotions. Development in the area of emotional intelligence can be exemplified by acceptance and commitment therapy. The limitation of this study may be a relatively small number of actors participating $(N=52)$. It is also worth exploring other areas that may be involved in explaining variances in the sense of quality of life, such as job satisfaction, professional achievements or the level of perceived stress. The issue of cognitive evaluation in the context of the situation of public performances in actors also seems interesting.

The authors want to thank the actors from the following theaters for taking part in the research (random order, original names): Nowy Teatr im. Witkacego w Słupsku, Teatr Dramatyczny im. Aleksandra Węgierki w Białymstoku, Teatr im. Ludwika Solskiego w Tarnowie, Bałtycki Teatr Dramatyczny im. Juliusza Słowackiego w Koszalinie, Teatr im. Adama Mickiewicza w Częstochowie, Teatr im. Stefana Jaracza w Łodzi, Teatr Rozrywki w Chorzowie, Teatr Miejski w Gliwicach, Teatr im. St. I. Witkacego w Zakopanem, Teatr im. Juliusza Osterwy w Lublinie. 


\section{CReditT Author Statement}

WOJCIECH NAPORA (60\%): conceptualization, methodology, validation, formal analysis, investigation, resources, data curation, writing (original draft), writing (review and editing), supervision, project administration.

ANDRZEJ SĘKOWSKI (40\%): conceptualization, methodology, validation, writing (original draft), writing (review and editing), project administration, formal analysis, supervision.

\section{REFERENCES}

Al-Huwailah, A. (2017). Quality of life and emotional intelligence in a sample of Kuwait University students. Journal of Education and Practice, 8(3), 180-185.

Banks, S., \& Kenner, A. (1997). Are actors more socially skilled? Behavioral and self report measures. Psychological Reports, 81(3), 1115-1123.

Bonna, B. (2003). Rola sztuki w życiu człowieka [The role of art in human life]. Kultura I Edukacja, $3-4,59-70$.

Branden, N. (1969). The psychology of self-esteem. Bantam.

Cobb, C. D., \& Mayer, J. D. (2000). Emotional intelligence. What the research says. Educational Leadership, 58, 14-18.

Czapiński, J. (2008). Czy szczęście popłaca? Dobrostan psychiczny jako przyczyna pomyślności życiowej [Does happiness pay off? Mental well-being as the cause of life well-being]. In J. Czapiński (Ed.), Psychologia pozytywna. Nauka o szczęściu, zdrowiu, sile i cnotach człowieka (pp. 235-254). Państwowe Wydawnictwo Naukowe.

Dolińska, D. (2013). Mowa ciała jako aspekt komunikacji międzyludzkiej [Body language as anaspect of interpersonal communication]. Zeszyty Naukowe Politechniki Śląskiej, 65, 101-110.

Dzwonkowska, I., Lachowicz-Tabaczek, K., \& Łaguna, M. (2008). Samoocena i jej pomiar. SES [Self-esteem and measurement. SES]. Pracownia Testów Psychologicznych.

Filist, E. (2012). Samoocena a postawy młodzieży wobec zjawiska alkoholizmu [Self-esteem and attitudes of youth towards the phenomenon of alcoholism]. Innowacje Psychologiczne. Rozprawy i artykuty naukowe, 1(1), 47-53.

Filozofówna, I. (1976). Badania psychologiczne nad grą aktorską [Psychological research on acting]. In J. Degler (Ed.), Wprowadzenie do nauki o teatrze: Vol. 2. O tworzywie i twórcach dzieła teatralnego (pp. 345-366). Uniwersytet Wrocławski im. Bolesława Bieruta.

Frąckowiak, T. (2004). Personalistyczno-egzystencjalna koncepcja poczucia jakości życia. Próba operacjonalizacji [Personalistic-existential concept of the sense of the quality of life: An attempt at operationalization] (Master's thesis, Uniwersytet Wrocławski, Wrocław, Poland).

Friedman, H. S., Prince, L. M., Riggio, R. E., \& DiMatteo, M. R. (1980). Understanding and assessing non-verbal expressiveness: The affective communication test. Journal of Personality and Social Psychology, 39, 333-351.

Goldstein, T., \& Bloom, P. (2011). The mind on stage: why cognitive scientists should study acting. Trends in Cognitive Science, 15(4), 141-142. https://doi.org/10.1016/j.tics.2011.02.003 
Goleman, D. (1999). Inteligencja emocjonalna w praktyce [Emotional intelligence in practice]. Media Rodzina.

Greenier, K. D., Kernis, M. H., \& Waschull, S. B. (1995). Not all high (or low) self-esteem people are the same: Theory and research on stability of self-esteem. In M. H. Kernis (Ed.), Efficacy, agency, and self-esteem (pp. 51-71). Springer.

Hammond, J., \& Edelmann, R. J. (1991). The act of being: Personality characteristics of professional actors, amateur actors and non-actors. In G. D. Wilson (Ed.), Psychology and Performing Arts (pp. 123-131). Swets \& Zeintlinge.

Henne, K. (2003). Kompetencja społeczna i inteligencja emocjonalna a zaangażowanie w Internet [Social competence and emotional intelligence and involvement in the Internet]. Psychologia Jakości Życia, 2(1), 111-130.

Hys, A., \& Nieznańska, A. (2001). Osobowość a style radzenia sobie ze stresem u aktorów teatralnych [Personality and stress coping styles in theater actors]. Studia Psychologica, 2, 51-54.

Hys, A., \& Nieznańska, A. (2007). Aktorzy teatralni [Theater actors]. In J. Terelak (Ed.), Stres zawodowy (pp. 46-86). Wydawnictwo UKSW.

James, W. (1890). The principles of psychology. H. Holt and Company.

Jaworowska, A., \& Matczak, A. (2005). Popularny Kwestionariusz Inteligencji Emocjonalnej PKIE. Podręcznik [Popular Emotional Intelligence Questionnaire. A Handbook]. Pracownia Testów Psychologicznych Polskiego Towarzystwa Psychologicznego.

Kermode, R., \& MacLean, S. (2001). A study of the relationship between quality of life, self-esteem and health. The Australian Journal of Advanced Nursing, 19(2), 33-40.

Kociuba, J. (1996). Tożsamość aktora [Actor's identity]. Wydawnictwo UMCS.

Konijn, E. A. (2000). Acting emotions. Shaping emotions on stage. Amsterdam University Press.

Łaguna, M., Laczowicz-Tabaczek, K., \& Dzwonkowska, I. (2007). Skala samooceny SES Morrisa Rosenberga - polska adaptacja metody [Morris Rosenberg's SES Self-Esteem Scale: The Polish adaptation of the method]. Psychologia spoleczna, 2(4), 164-176.

Martowska, K., Matczak, A., \& Jóźwik, K. (2018). Overexcitability in actors. Psychology of Aesthetics, Creativity, and the Arts, 14(1), 81-86. https://doi.org/10.1037/aca0000192

Matczak, A., \& Jaworowska, A. (2001). Kwestionariusz Kompetencji Spolecznych [Questionnaire of Social Competences]. Pracownia Testów Psychologicznych Polskiego Towarzystwa Psychologicznego.

Mróz, B. (2008). Osobowość wybitnych aktorów polskich [Personality of outstanding Polish actors]. Scholar.

Mróz, B. (2011). Poczucie jakości życia u pracowników wyższego szczebla. Uwarunkowania osobowościowe i aksjologiczne [Sense of quality of life in senior employees. Personality and axiological conditions]. Scholar.

Mróz, B. (2015). 20 lat później - osobowość i hierarchia wartości wybitnych aktorów polskich [20 years later: Personality and hierarchy of values of outstanding Polish actors]. Scholar.

Mróz, B. (2016). Poczucie jakości życia osób z kadry kierowniczej w świetle Modelu Osobowościowo-Aksjologicznego MOA [Sense of quality of life in managers in light of the MOA Personality-Axiological Model]. Czasopismo Psychologiczne, 22(2), 183-194.

Mróz, B. (2017). Longitudinal research into purpose in life in outstanding Polish actors. Polish Journal of Applied Psychology, 15(1), 19-36.

Mróz, B. (2018). Art of acting and management style. Results of psychological research on personality and hierarchy of values of outstanding Polish actors and managers in the area of services. Edukacja Ekonomistów i menedżerów, 4(50), 145-158. https://doi.org/10.5604/01.3001.0013.0638 
Mróz, B., Chudzicka-Czupała, A., \& Kuśpit, M. (2017). Kompetencje osobowościowe i twórcze. Psychologiczne uwarunkowania kreatywności pracowników [Personal and creative competences. Psychological determinants of employees' creativity]. Scholar.

Mróz, B., Kociuba, J., \& Osterloff, B. (2017). Sztuka aktorska w badaniach psychologicznych i refleksji estetycznej [Acting in psychological research and aesthetic reflection]. Scholar.

Mróz, B., \& Kurzyca, J. (2018). Poczucie jakości życia i hierarchia wartości - różnice między studentami kierunków społecznych i technicznych [Sense of quality of life and the hierarchy of values: Differences between students of social and technical faculties]. Czasopismo Psychologiczne, 24(3), 509-518.

Nettle, D. (2005). Psychological profiles of professional actors. Personality and Individual Differences, 40, 375-383. https://doi.org/10.1016/j.paid.2005.07.008

Niewiadomska, I., \& Chwaszcz, J. (2010). Jak skutecznie zapobiegać karierze przestępczej? [How to effectively prevent a criminal career?]. DrukarniaTekst.

Oleś, P. (2002). Jakość życia w zdrowiu i chorobie [Quality of life in health and disease]. In P. Oleś, S. Steuden, \& J. Toczydłowski (Eds.), Zaburzenia widzenia a jakość życia (pp. 37-52). Towarzystwo Naukowe KUL.

Oleszko-Molik, E. (2012). Jak swobodnie operować głosem. „Voice and Body” Zygmunta Molika - bez tajemnic [How to freely operate your voice: "Voice and Body" by Zygmunt Molik - No secrets]. Zeszyty Naukowe Państwowej Wyższej Szkoły Teatralnej im. Ludwika Solskiego w Krakowie, 4, $61-68$.

Orlak, K. (2009). Zagrożenia psychospołeczne na stanowisku aktor [Psychosocial threats for an actor]. Psychologiapracy, 11, 52-55.

Orpinas, P. (2010). Social competence. In I. B. Weiner \& W. E. Craighead (Eds.) The Corsini Encyclopedia of Psychology (pp. 1623-1625). John Wiley \& Sons.

Pastuszak, A. (2012). Regulacja emocji u pacjentów z zaburzeniem osobowości borderline - aktualne kierunki badań [Emotion regulation in patients with borderline personality disorder: Current directions of research]. Psychiatria Polska, 46, 401-408.

Petelewicz, M., \& Drabowicz, T. (2016). Jakość życia - globalnie i lokalnie. Pomiar I wizualizacja [Quality of life-Globally and locally: Measurement and visualization]. Katedra Socjologii Ogólnej, Uniwersytet Łódzki, Poland.

Peters, T. C. (2001). The relationships between acting experience, self-esteem, and self-monitoring. Modern Psychological Studies, 7(1), 33-37.

Przybylska, I. (2007). Inteligencja emocjonalna a uzdolnienia twórcze i funkcjonowanie szkolne młodzieży [Emotional intelligence versus creative abilities and school functioning of young people]. Wydawnictwo Uniwersytetu Śląskiego.

Saarni, C. (1999). The development of emotional competence. Guilford Press.

Sarason, B. R., Sarason, I. G., Hacker, T. A., \& Basham, R. B. (1995). Concomitants of social support: Social skills, physical attractiveness, and gender. Journal of Personality and Social Psychology, 49, 69-480.

Sękowski, A. E. (1989). Osobowość a osiagnięcia artystyczne uczniów szkół muzycznych [Personality and artistic achievements of music school students]. Polska Akademia Nauk.

Sękowski, A. E. (2006). Postawy społeczne a poczucie jakości życia osób niepełnosprawnych [Social attitudes and the sense of quality of life in disabled people]. In Z. Palak (Ed.), Jakość życia osób niepetnosprawnych i nieprzystosowanych spolecznie (pp. 29-37). Wydawnictwo UMCS.

Spencer, R. J., Josephs, R. A., \& Steele, C. M. (1993). Low self-esteem. The uphill struggle for self-integrity. In R. F. Baumeister (Ed.), Self-esteem. The puzzle for low self-regard (pp. 21-36). Plenum Press. 
Straś-Romanowska, M. (1992). Los człowieka jako problem psychologiczny: podstawy teoretyczne [Human fate as a psychological problem: Theoretical foundations]. Wydawnictwo Uniwersytetu Wrocławskiego.

Trawka, K. (2006). Jak afekt i samoocena kształtują jakość życia - badania eksperymentalne [How affect and self-esteem shape quality of life: Experimental research]. In Prace Naukowe Akademii im. Jana Dlugosza w Częstochowie. Psychologia XIII (pp. 77-92). Wydawnictwo Akademii im. Jana Długosza w Częstochowie.

Zamorska, G. (2015). Kompetencje emocjonalne i społeczne a funkcjonowanie w pracy [Emotional and social competences and functioning at work]. Paper presented at the Third Student Scientific Conference, WSPIA Rzeszów, Poland. 